\title{
Research on Striving for "Double First-class": Possibilities and Challenges of Private Colleges and Universities
}

\author{
Zhang Yan \\ Qi Fang Education Research Institute, Xi’an International University, Xi’an, Shaanxi, 710077
}

Keywords: "Double First-class” construction; private colleges and universities; challenge

\begin{abstract}
Double First-class" policy will lead the further development of the private higher education in China, so every private college or university must try itself to be a "Double First-class" school, which is not only the requirement of establishing a good competitive ecological environment of the system of higher education in China, but also the inevitable developmental trend that Chinese private colleges and universities become should be neck to neck with the advanced higher education of other countries. Although there are some factors which are favorable to the "Double First-class" development of the private colleges and universities such as historical condition, political condition, and economic condition, as well as the relative advantageous internal system and the elementary talents cultivation condition, but from the perspectives of the administrative levels and teaching levels of the private colleges and universities, there is still a huge gap between these private schools and the first-class universities, which is mainly reflected in a clear conflict between public welfare of private higher education and the profit-making feature of capital, the relationship between the private colleges and universities and the government which is relative not well, the insufficient resources of running private schools and the relevant supports, the low construction level of the disciplines and majors of the private colleges and universities, and lots of choke points blocking the team building of the teachers in the colleges and universities.
\end{abstract}

\section{Introduction}

At the end of 2015, the State Council officially issued the Overall Plan for Promoting the Construction of the First-class Chinese Universities and Disciplines in the World ("the Plan" for short below), which drew a new blueprint for the development of higher education in the next 30 years, and the Plan provides strong support for achieving the goals of "Two Centenary Years" and "Chinese Dream". In the new round of main national policy adjustment, whether the private colleges and universities "stay out of the matter" and "watch a fire from the other side," or seize this opportunity and make progress actively so as to strive for first-class, which, to a large extent, will determine the future development of the private colleges and universities.

\section{To Strive for "Double First-class": Possibilities of the Private Colleges and Universities}

We cannot predict how many private colleges and universities in China will be the top universities of China, and how many will be the top universities in the world, however, we believe that as long as we unswervingly push forward the reform of the system and mechanism, and let the private higher education burst out its potential vitality and creativity, a number of attractive and high-level private colleges and universities will certainly stand out from the crowd.

Private education in China has lasted for more than 2000 years. In the process of coexisting with official education, although it has always been in a marginal and non-mainstream position, but it has still cultivated a great number of talents who are the elites for the country generation after generation; and it had created the top private education in ancient China. Private education has a long cultural tradition and a deep public foundation in China, it is not only the cultural factor that Chinese contemporary private education can be reestablished and developed rapidly after decades of interruption, but also the historical and cultural condition for China will rebuild some first-class private colleges and universities in the future. During the Republic of China (1912-1949), there 
were a lot of high-level private universities in China such as Jinling University, Yanjing University, Nankai University and so on. From 1951 to 1953, the adjustment of faculties and departments of the colleges and universities throughout the country made private universities, which have been active for nearly a century, disappeared from the Chinese educational stage.

After the resumption of contemporary private higher education, the scale and quantity of private higher education have increased rapidly, and the structure of the private higher education has shown obvious characteristics of regional unbalanced development. Of course, due to the short developmental history of the private higher education in contemporary China and the limitations of the special national conditions, the overall developmental level and the quality of education and teaching have not yet recovered to the highest level of private higher education before, it is still in the initial developmental stage, this is the actual developmental foundation of constructing the first-class private universities of China in the future.

Private education is the production of the interaction of non-public economy and social organization. Private higher education in China is produced under the background of the serious shortage of public higher education resources and the inability of meeting the increasing educational needs of the public. It has distinct characteristics of spontaneity, marketability, and that it expands its living space from bottom to top. The contradiction between supply and demand of higher education in China has existed for a long time, and the serious shortage of educational funds is not only the market background for the resumption of private higher education, but also the economic driving force for the further development of private higher education. If the public colleges and universities want to create "double first-class", the main financial support is the national financial funds, if we only to construct the world-class public universities without private universities, it may bring the dilemma that "create a few winners, but at the expense of the majority". Because of its flexible running system and better economic efficiency, private colleges and universities can make full use of private capital, increase the ways of obtain funds for the construction of "double first-class" in China, and create two channels----national financial subsidies and private funds---- of building "double first-class".

Since China had adopted the Reform and Opening Up policy, as the constant growth of economy, the adjustment of industrial structure, the reorganization of social strata and the differentiation of interests, the demands of the public for higher education have become more and more diversified. The different industries and posts require different talents, and the demands of people for individualized, characteristic and high-level higher education are increasing. Obviously, the public resources of higher education are limited, the high-quality resources and the resources that can meet the selective demand are much rarer, so there is an urgent need for educational services of different types, levels and forms to cultivate all kinds of talents for the society. The prosperity of the private higher education in China began from increasing the supply of higher education resources and letting more people enjoy higher education. In the future, it will gradually change to meet the different demands of the public. Different demands, especially the increase of selective demand, may promote the historic transformation of private higher education of China.

Private higher education is a part of the whole higher education, if there is no reform on higher education, its relevant educational management system and the talent cultivation model, the higher education is impossible to achieve rapid progress. However, the situation of the private higher education in China is developing in a positive direction----as the gradual development of the modernization of the governance system and governance capacity of China government, and the various favorable reforms and policies for the development of higher education has been put into force, the higher education has been on the eve of great change. As long as private colleges and universities constantly strive for surpassing themselves, improve their teaching quality, set up their own characteristics, base on the reality, and have the international view, it is not impossible to achieve the goal of catching up with the first-class universities or surpassing them.

After more than 30 years of development, China's private higher education has experienced from nothing to a few, from a few to a lot, from weak to strong, from single to pluralistic, from disorder to standard; and it has formed a variety of higher education system with various types, it is full of 
vitality and unique characteristics, and it has become an important part of the higher education in China and an important driving force of educational reform. Private colleges and universities have made a great deal of explorations in the aspects of internal management, education and teaching, talent cultivation and so on. In particular, it is exploring a new way on cultivating the applied and skilled talents, and it is showing a strong vitality of reform; all these above have laid a relative solid foundation for achieving the goal of becoming a first-class university to the private colleges and universities.

\section{To Strive for "Double First-Class": Challenges of the Private Colleges and Universities}

From the 1980s to now, after more than thirty years development, China's private higher education, from nonexistence to pass into existence, from small to large, from weak to strong, is showing a tenacious vitality and vigorous creativity. Especially since the promulgation and implementation of the Private Education Promotion Law in 2002, private higher education has made great progress, and has become an indispensable and important part of the cause of higher education in China. By now, the private education in China has formed a certain scale of system that is multi-level, multi-form, and multi-regional. By 30th May 2016, there were 2879 colleges and universities in China (including 284 adult schools, 5 Chinese-foreign cooperative schools, 2 cooperative schools of mainland and Hong Kong, Macao or Taiwan), 735 private colleges and universities (including 1 adult institution of higher education), which account for $25.53 \%$ of the total number of colleges and universities in China. However, from the administrative levels and the teaching levels of running schools, private higher education in China is still in a relatively low stage of development; compared with the international first-class universities, the private colleges and universities in China still lag the first-class schools a lot; the problems are shown in the following aspects:

Most private colleges and universities are not some as the public universities; they acquire educational financial funds by means of tuition fees, loans or establishing companies that attach to them. The investment from private capital has brought vitality and opportunity for the further development of private higher education, but the nature of the capital----pursuing the interests----has made quite a number of private university organizers blindly cater to the market and pursue low costs and high incomes. They forget the basic principle and basic value of education, neglect and nature of commonweal of education, so that educational value is imbalance and the educational quality becomes worse and worse; these problems lead to the potential risks of running a school.

At present, the relationship between the government and the private colleges and universities is not satisfied, the functions of government sometimes are not suitable for the development of the private schools. On one hand, some government departments are accustomed to administrate the private colleges and universities as they administrate the public schools, and excessively interfere in the running of private colleges and universities, so that the flexibility and mobility of the private schools which are suitable for the market could not be brought into play effectively, these are not conducive to the characteristic development of private colleges and universities. On the other hand, supervision of the government is weak and the means of regulation are unitary. The phenomenon that some departments of government only examine and approve without supervision is still quite common; some government officers still have the attitude of "do not want to administrate, dare not administrate, can not administrate " to the affairs of private schools, and do not act an active role, so as to lead some non-standard behaviors of some private colleges and universities in running schools. In addition, with the habitual mode of thinking, the administrative departments that are related to education still supervise the private schools only by means of administrative methods which are backward, old, and which greatly dampen the enthusiasm of the private colleges and universities in running schools.

At the beginning of most private colleges and universities' development, they mainly depend on expanding the scale of the students to ensure the running expenses. At present, private colleges and universities are in the period of development and reformation, and the private higher education has 
entered the stage of focusing on the key factors that block the development of it; the colleges and universities have tried their best to provide high-level and high-quality education services to the public. On one hand, the construction of high-level schools requires more resources and funds, on the other hand, as the number of the students of private colleges and universities continue decreasing, the ways for these private schools to acquire funds and resources that are available have been becoming less and less. Although some provinces and cities have set up special funds for the private education, however, the total subsidy for the private colleges and universities is still like a drop in a bucket.

The world-class universities that we often refer to are famous because of their lots of advanced and characteristic disciplines. A top-class university must have top-class discipline. In order to cultivate high-quality innovative applied talents, private colleges and universities must pay more attention to the construction of disciplines and majors, and that is the most important basic work of colleges and universities. At present, most private colleges and universities in China have not been established for a long time, they are lack of accumulation of experiences on the construction of discipline, and have the weak foundation in running schools. Although many private colleges and universities have established a lot of disciplines in their schools, they are far from the requirements of building a first-class private university, the characteristics of their disciplines and majors are not prominent, at the some time, these disciplines and majors can not be connected harmoniously and systematically. So the private colleges and universities face the tuff task of strengthening the construction of disciplines and cultivating the talents.

Due to the lack of guarantee system, low salary, limited space for teachers' career development, and discrimination of identity, for the private colleges and universities, the high-level leader who can lead a special team that researches certain discipline is hard to employ, and the teachers' ranks are very unstable; in particular, some private colleges and universities only seek for profit blindly, and the investment in the team building of teachers is limited, so lots of teachers in private colleges and universities select to leave. Although many private colleges and universities have taken a lot of active and effective measures for strengthening their team building of teachers, and they have achieved certain results, but there still are some problems such as too many young teachers who are little experiences or old teachers who will be retired soon; the excellent teacher is rare; the "double-position teacher" is relative few; scientific research ability of the teachers is weak and so on.

\section{Acknowledgements}

Pro: Scientific Research Program Funded by Shaanxi, Provincial Education Department (Program No. 13JZ075)

\section{References}

[1] Pan Maoyuan. Preface of A study on the Development of Private Higher Education in China[M]. Zhejiang University Press, 2005(7):1

[2] Wang Yitao. Exploration on the Feasibility of High level Private Colleges and Universities[N]. China Education Daily, 2016-4-7

[3] Li Guirong, Hao Lianru. Internal Advantages and External Conditions on Constructing Modern University System in Private Universities[J]. Education and Vocation, 2014(32):48-50

[4] Xiong Bingqi. "Double First-class": To Build World-class Chinese Universities version 2.0[J]. People's Tribune, 2016(7) 